Association for Information Systems AIS Electronic Library (AISeL)

December 2004

\title{
The Evolution of Corporate Web Presence: A Longitudinal Study of Large American Companies
}

Nathan Heinze

Florida Atlantic University

Qing $\mathrm{Hu}$

Florida Atlantic University

Follow this and additional works at: http://aisel.aisnet.org/amcis2004

\section{Recommended Citation}

Heinze, Nathan and Hu, Qing, "The Evolution of Corporate Web Presence: A Longitudinal Study of Large American Companies" (2004). AMCIS 2004 Proceedings. 291.

http://aisel.aisnet.org/amcis2004/291 


\title{
The Evolution of Corporate Web Presence: A Longitudinal Study of Large American Companies
}

\author{
Nathan Heinze \\ Department of Information Technology and \\ Operations Management \\ College of Business Administration \\ Florida Atlantic University \\ Boca Raton, FL 33431 \\ Nathan535@earthlink.net
}

\author{
Qing Hu \\ Department of Information Technology and \\ Operations Management \\ College of Business Administration \\ Florida Atlantic University \\ Boca Raton, FL 33431 \\ Qhu@fau.edu
}

\begin{abstract}
This paper presents the results of a six-year longitudinal survey of the web sites of S\&P 500 companies. Using nine design and functional measures developed based on prior research, we find that S\&P 500 companies have experienced significant transformation of their web presence, signified by the increasing levels of information and interactivity. We find a continuing trend toward increasing numbers and types of features offered, suggesting that large companies are placing greater importance on the customer orientation of their web sites in order to attract and maintain a profitable customer base. The findings of this study offer guidelines to managers for creating a web presence that improves customer and shareholder perception of the company, increases customer loyalty, and facilitates the execution of e-commerce strategies. The results of this study also provide a foundation for further research on the relationships among customer perceptions, customer loyalty, and financial performance.
\end{abstract}

\section{Keywords}

Web Presence, Web Features, Web Metrics, E-Commerce, S\&P 500.

\section{INTRODUCTION}

While there is little doubt in the literature about the importance of having a web presence, it is not clear as to what features and functions a corporate web site should have in order to accomplish its intended purposes. Thus far, most studies have attempted to identify what factors are important in attracting web users (Barnes and Vidgen, 2003; Devaraj, Fan and Coli, 2002; Koufaris, Kambil and LaBerbera, 2001; Reibstein, 2002; Teo, Oha, Liu and Weib, 2003; Torkzedah and Dhillon, 2002; Zhang and Dran, 2002). This stream of research has employed a number of metrics to measure items related to service, trust, interactivity, and information availability. However, many of these studies are explorative in nature and rely on participant perceptions (e.g., opinions and impressions) on specific web sites. What has been rare in the literature is a more systematic and objective study of what the corporate world is actually doing and how they are doing it in terms of building a web presence. Zhu and Kraemer (2002) correctly point out that what is needed at this point are large-sample statistical surveys.

In this paper, we attempt to address this need by examining each and every Standard \& Poor's (S\&P) 500 company web site over a period of six years. The S\&P 500 was chosen because of its broad base of companies, making it predictive of large American firms as a whole. The focus of this study is not to ascertain customer perceptions of the sites, but to closely examine the actual feature sets of the these web sites. In essence, we attempt to investigate the progress the S\&P 500 corporations are making in implementing web site features that other studies have shown to be important and to make sense of why such progress has taken place over the last decade. Once a solid base of such information is established, it will be possible to conduct studies on whether or not companies that implement certain web site features experience improved financial performance, as many e-commerce studies have argued. We view our study as an important piece in establishing the link between web presence and company performance.

\section{RESEARCH BACKGROUND}




\section{The Benefits of Web Presence}

In the increasingly competitive digital economy, a strong online presence is generally considered an important component of most large organizations. Users are continually expecting more web site features and services (Zhang and Dran, 2002), and a company that offers a dull and uninformative site is at a disadvantage. An attractive and functional web site that invites customer use is in most cases an antecedent to online success (Ghose and Dou, 1998; Teo et al., 2002; Wu 1999). However, even if a web site is easily navigated and well-designed, it is not a given that it will contribute to the bottom line of the company. Even if a company is able to gain in online sales, the more important challenge is to achieve and sustain repeat business (Reichheld and Schefter, 2000; Chen and Hitt, 2002). A well-designed and feature-rich web site can contribute to achieving this goal.

The possible benefits of a firm's web presence, such as increased name recognition, better customer service, and increased sales, are likely to be realized to a fuller extent if customers have positive perceptions of the firm's web site. There are a number of features that have been shown to be important in contributing to user perceptions. Our literature review identified four of the most commonly researched attributes of web site success: trust (Han and Noh, 2000; Lee and Turban, 2001; McKnight, Choudhury and Kacmar, 2002; Torkzadeh and Dhillon, 2002), service (Devaraj et. al, 2002; Janda, Trocchia and Gwinner, 2002; Liu and Arnett, 2000; Rust and Lemon, 2001), information (Devaraj et. al, 2002; Huizingh 2000; Keeney 1999; Kim, Lee, Han and Lee, 2002; Morris and Turner, 2001; Madeja and Schoder, 2002; Palmer, 2002; Wan 2000; Zhu and Kraemer, 2002), and interactivity (Ghose and Dou, 1998; Madeja and Schoder, 2002; McKinney, Yoon and Zahedi, 2002; Teo et al., 2002; Wu 1999). If a firm's web site includes features that are shown to have a positive effect on customer perceptions, more benefits should be realized such as increased sales levels and higher degree of customer loyalty (Amit and Zott, 2001).

\section{Measurement of Web Site Effectiveness}

Even though the four attributes, trust, service, information, and interactivity, have been shown to have a direct relationship with customer perceptions and/or use of web sites, only two, information and interactivity, are used in our current study for two reasons. First, the line separating service and interactivity is not always clear. Previous studies have justifiably used items such as FAQs, online chat, search engines (Teo, et al., 2002) and real-time support (Zhu and Kraemer, 2002) to measure interactivity instead of service, and because of this precedent, we found it appropriate to use similar metrics as indicators of interactivity instead of service. Second, trust is a subjective attribute and is best studied using a more customer oriented method than the one we have chosen.

The levels of information and interactivity have been measured using a number of different metrics. The subject of how to measure the effectiveness of web sites is still in its formative stages, and discussion continues on the topic of the most effective metrics (Straub et al., 2002). However, as more studies are published, certain patterns have emerged in the literature, an indication of convergence within studies of web site effectiveness. Tables 1 and 2 list metrics that have been used to measure interactivity and information.

\begin{tabular}{|l|l|}
\hline Interactivity Metrics & Source \\
\hline Feedback forms, Search engines, Online forums, Online chat, FAQ & Teol. (2003) \\
\hline $\begin{array}{l}\text { Configuration ability, Customer registration, Online recommendation, } \\
\text { Content-personalization, Real-time support. }\end{array}$ & Zhu and Kraemer (2002) \\
\hline $\begin{array}{l}\text { Create a list of items, Change a list of items, Create a customized } \\
\text { product, Select different features of the products. }\end{array}$ & McKinney et al. (2002) \\
\hline \begin{tabular}{l} 
Customization \\
\hline
\end{tabular} & Palmer (2002) \\
\hline
\end{tabular}

Table 1: Interactivity Metrics 


\begin{tabular}{|c|c|}
\hline Information Metrics & Source \\
\hline $\begin{array}{l}\text { Accurate information, Believable information, Timely information } \\
\text { Relevant information, Easy to understand information, Information at } \\
\text { the right level of detail, Information in an appropriate format }\end{array}$ & Barnes and Vidgen (2003) \\
\hline $\begin{array}{l}\text { Information on Web site stays for a reasonable period of time, Absence } \\
\text { of improper materials, Accurate information, Appropriate detail level of } \\
\text { information, Up-to-date information, Relevant information, Complete } \\
\text { coverage of information, Content that supports web site's intended } \\
\text { purpose, Controversial materials, Novel (new) information }\end{array}$ & Zhang and Dran (2002) \\
\hline Relevance, Media use, Depth/breadth, Current/ timely information & Agarwal and Venkatesh (2002) \\
\hline $\begin{array}{l}\text { Information quality relevant, Accurate, Timely information, Flexible and } \\
\text { customized information, Presentation, Products/services differentiation, } \\
\text { Complete description of products/services, Price information, Satisfying }\end{array}$ & Liu and Arnett (2000) \\
\hline $\begin{array}{l}\text { Information related to goods and services offered is accurate } \\
\text { Whether site provides information on item name, brand, price, images }\end{array}$ & Kim et al. (2002) \\
\hline Quantity of information, Variety of information & Palmer (2002) \\
\hline $\begin{array}{l}\text { Product information online, Search capability, Product review, Product } \\
\text { information update }\end{array}$ & Zhu and Kraemer (2002) \\
\hline Understandability, Reliability, Usefulness & McKinney et al. (2002) \\
\hline
\end{tabular}

Table 2: Information Metrics

\section{RESEARCH METHOD AND DATA}

This study was conducted over a period of six years, with data sampling taking place in 1997, 2000, and 2003. In each of the three years, visits were made by the researchers and their assistants to each of the S\&P 500 web sites in order to ascertain the feature set of each site. The attributes of the web sites were accordingly measured, recorded and classified. A snapshot of each of the web sites sampled was archived for later use in case re-sampling of the sites are needed.

The metrics used in this study were developed based on a literature review performed prior to the 1997 sampling. Product Advertisement, Product Information, Career Opportunities, and Investor Information are used as measures of information. Support Contact, Customer Support, Online Sales, and Online Account Access are measures of interactivity. These metrics are described in Tables 3 and 4 . 


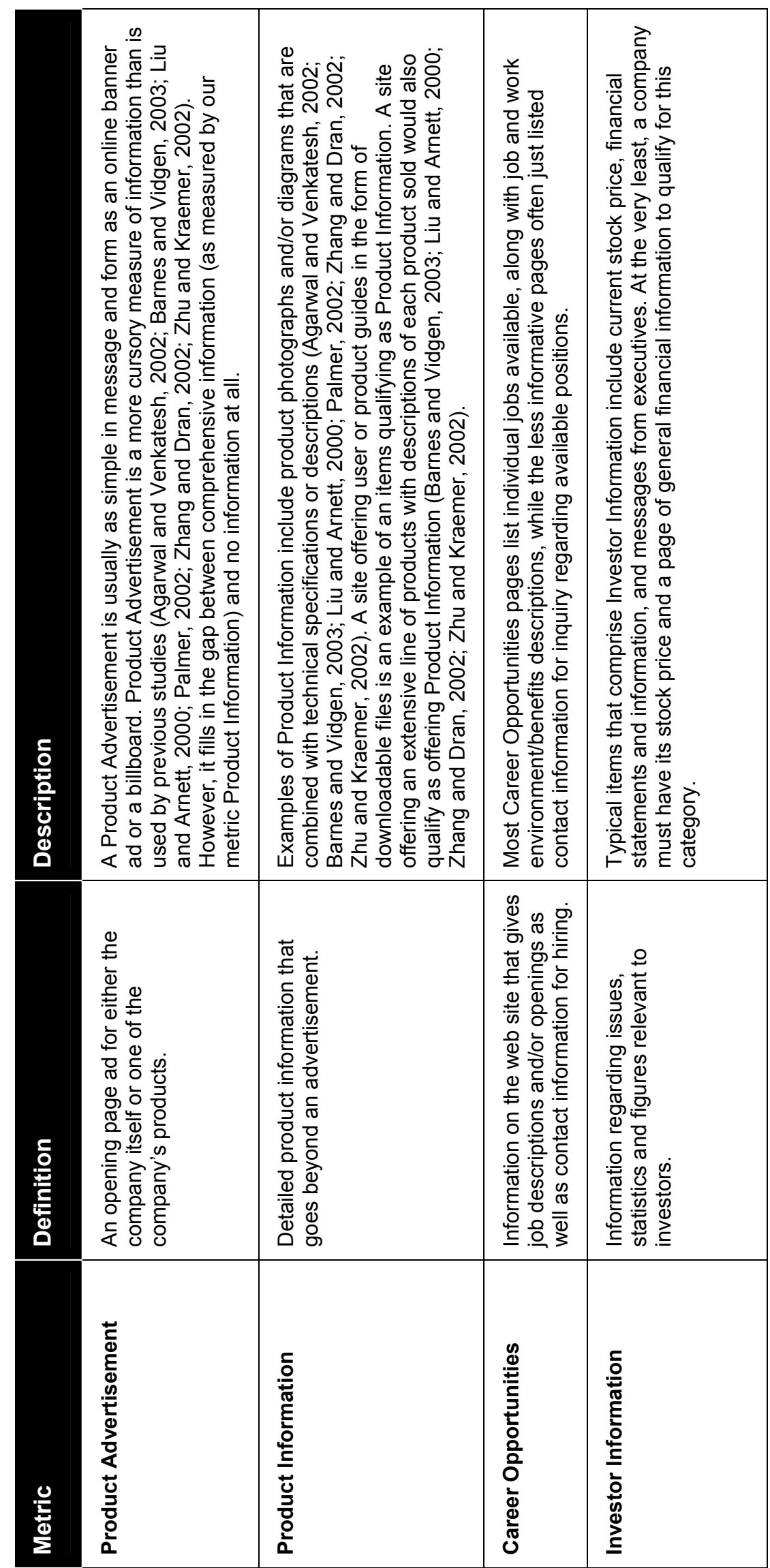




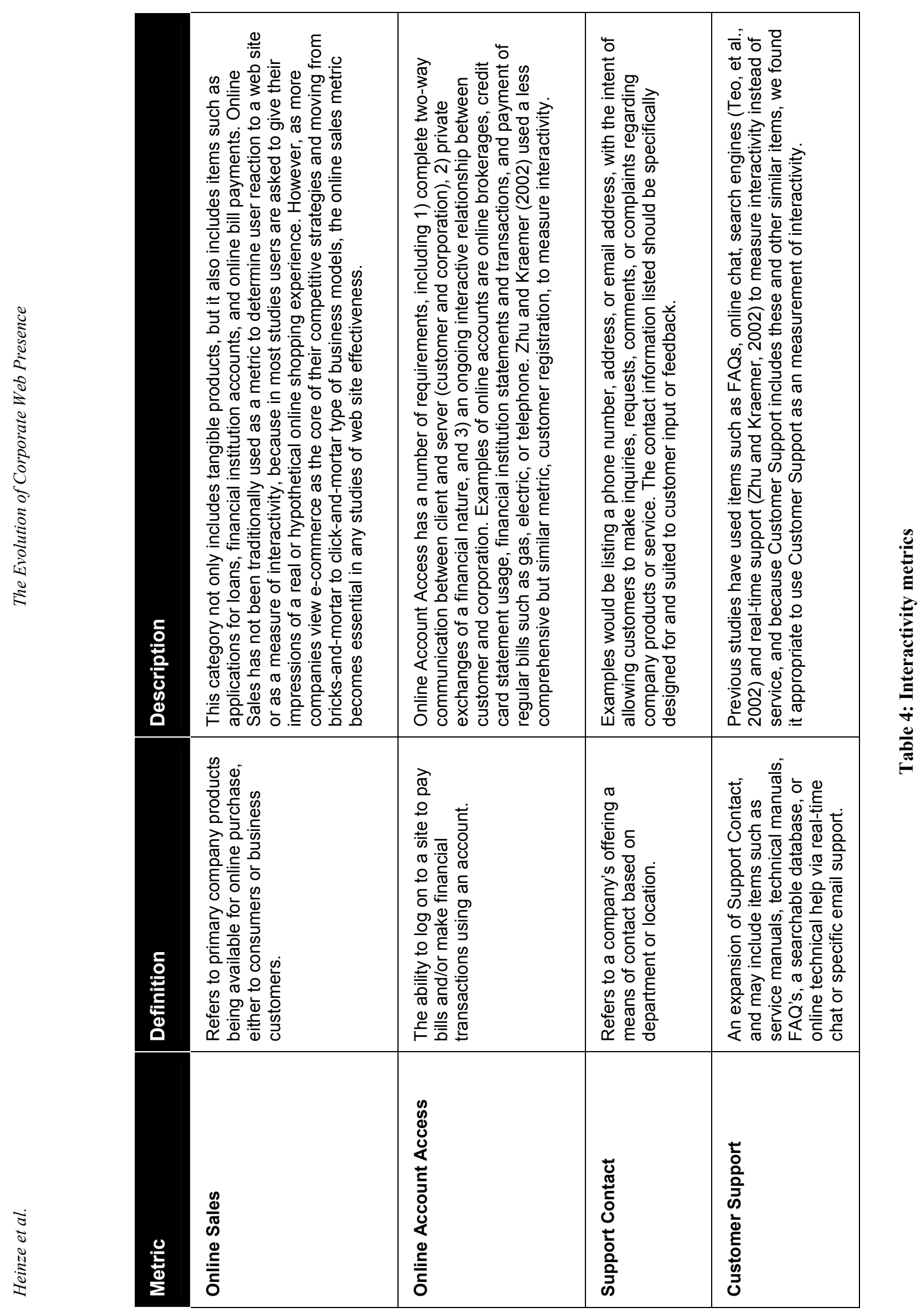




\section{RESULTS AND DISCUSSION}

As shown in Table 5, the trend over the past six years has clearly been towards higher levels of information and interactivity, as indicated by the number of web sites that incorporate these eight features. Every single feature has seen increased use from one period to the next except for Support Contact between 2000 and $2003(-7.4 \%)$. The most dramatic trends are the increases in Customer Support, Online Sales, and Online Account Access. Customer Support increased by 171\% from 1997 (69 firms) to 2000 (187 firms) and 15.5\% from 2000 to 2003 (216 firms). Online Sales increased by 108.5\% from 1997 (71 firms) to 2000 (148 firms) and 70.3\% from 2000 to 2003 (252 firms). Finally, Online Account Access increased by 132.5\% from 2000 to 2003 (186 firms). Figures 1 to 3 show the overall trend of these three import web site features in S\&P500 company web sites across all industries.

\begin{tabular}{|l|c|c|c|c|c|}
\hline \multicolumn{1}{|c|}{ Categories } & ${ }^{* 1997}$ & \multicolumn{2}{c|}{$\mathbf{2 0 0 0}$} & \multicolumn{2}{c|}{$\mathbf{2 0 0 3}$} \\
\hline & \% With & \% With & $\begin{array}{c}{ }^{* *} \text { Change } \\
\text { from 1997 }\end{array}$ & \% With & $\begin{array}{c}{ }^{* *} \text { Change } \\
\text { from 2000 }\end{array}$ \\
\hline Career Opportunities & $67.9 \%$ & $81.8 \%$ & $38.8 \%$ & $87.3 \%$ & $6.1 \%$ \\
\hline Customer Support & $15.9 \%$ & $37.5 \%$ & $171.0 \%$ & $43.5 \%$ & $15.5 \%$ \\
\hline Support Contact & $97.0 \%$ & $97.2 \%$ & $15.5 \%$ & $90.5 \%$ & $-7.4 \%$ \\
\hline Online Sales & $16.4 \%$ & $29.7 \%$ & $108.5 \%$ & $50.8 \%$ & $70.3 \%$ \\
\hline Product Advertisement & $100.0 \%$ & $87.2 \%$ & $0.5 \%$ & $92.7 \%$ & $5.7 \%$ \\
\hline Online Account Access & $5.6 \%$ & $16.0 \%$ & $185.7 \%$ & $37.5 \%$ & $132.5 \%$ \\
\hline Investor Information & $47.8 \%$ & $84.7 \%$ & $136.8 \%$ & $91.5 \%$ & $7.8 \%$ \\
\hline Product Information & $63.8 \%$ & $78.9 \%$ & $72.4 \%$ & $95.6 \%$ & $21.0 \%$ \\
\hline All Categories & $1.6 \%$ & $7.2 \%$ & $300 \%$ & $23.2 \%$ & $322.2 \%$ \\
\hline *Only 437 web sites in $1997{ }^{* *}$ based on number of web sites with each feature \\
\hline
\end{tabular}

Table 5: S\&P 500 web site trends

Even though these trends are consistent across all major industries as a whole within the S\&P 500, we believe it may yield more interesting information by comparing data across industries. To classify the sample companies into appropriate industries, we used the North American Industry Classification System (NAICS). The NAICS is the standard method of classifying business establishments. Adopted in 1997 to replace the old Standard Industrial Classification (SIC) system, it is the official industry classification system used by the statistical agencies of the United States. During the sampling period from 1997 to 2003, the largest industry for all three years was manufacturing with a six-year range of 42-45\%, followed by finance and insurance (11-13\%), information (8-10\%), retail trade (7\%), and utilities (7\%).

We then examined the trends for each of the five largest industries (manufacturing, finance and insurance, information, retail trade, and utilities). The goal was to find out whether or not there were differences among industries. If significant differences occur between industries, then the implications of the S\&P 500 trends for large corporations as a whole would be somewhat diluted because trends would be industry specific. However, it was found that the levels of all nine features were very similar across all industries except for manufacturing, where the numbers were dramatically divergent from the other industries, although the trends were similar.

Table 6 details trends within each of the five largest industries. Manufacturing represents the largest group of all companies in the S\&P 500 list. Not surprisingly, manufacturing trends reflect S\&P 500 trends as a whole, with Online Account Access, Online Sales, and Customer Support all exhibiting major increases within the six years. Like the overall market, Customer Support experienced a large increase between 1997 and 2000, with a milder increase between 2000 and 2003. The percentage of companies offering online sales went from $8.6 \%$ to $23.6 \%$ to $33.3 \%$, again reflecting trends in the S\&P 500 as a whole. The number of manufacturing companies with Online Account Access increased from seven to 32. From a percentage perspective, this represents a larger move than the market as a whole $(132.5 \%)$, but the percentage of manufacturing companies that offered Online Account Access was only 15.2\% compared to 37.5\% for the entire market. 


\begin{tabular}{|c|l|c|c|c|c|c|c|c|c|}
\hline Year & \multicolumn{1}{|c|}{ Industry } & \multicolumn{4}{|c|}{ Information (\%) } & \multicolumn{4}{c|}{ Interactivity (\%) } \\
\hline & & PA & PI & CO & II & OS & OA & SC & CS \\
\hline \multirow{4}{*}{1997} & Manufacturing & 86.7 & 66.5 & 57.5 & 57.1 & 8.6 & 0.0 & 84.1 & 8.6 \\
\cline { 2 - 11 } & Finance and Insurance & 96.5 & 85.9 & 73.7 & 56.1 & 31.6 & 22.8 & 96.5 & 33.3 \\
\cline { 2 - 11 } & Information & 90.2 & 68.3 & 65.9 & 46.3 & 31.7 & 0.0 & 87.8 & 29.3 \\
\cline { 2 - 11 } & Retail Trade & 77.1 & 34.3 & 62.9 & 31.4 & 25.7 & 2.9 & 74.3 & 2.9 \\
\cline { 2 - 10 } & Utilities & 97.2 & 61.1 & 66.7 & 61.1 & 11.1 & 11.1 & 97.2 & 16.7 \\
\hline \multirow{4}{*}{2000} & Manufacturing & 94.7 & 84.4 & 80.9 & 84.4 & 23.6 & 3.1 & 95.6 & 28.9 \\
\cline { 2 - 11 } & Finance and Insurance & 91.2 & 87.7 & 86.0 & 80.7 & 36.8 & 38.6 & 100.0 & 54.4 \\
\cline { 2 - 11 } & Information & 97.8 & 90.9 & 86.4 & 63.6 & 40.9 & 22.7 & 93.2 & 52.3 \\
\cline { 2 - 10 } & Retail Trade & 81.8 & 78.4 & 89.2 & 67.6 & 70.3 & 27.0 & 100.0 & 45.9 \\
\cline { 2 - 10 } & Utilities & 45.9 & 45.9 & 73.0 & 86.5 & 13.5 & 16.2 & 100.0 & 29.7 \\
\hline \multirow{4}{*}{2003} & Manufacturing & 94.3 & 95.7 & 86.7 & 91.9 & 33.3 & 15.2 & 87.1 & 32.4 \\
\cline { 2 - 10 } & Finance and Insurance & 92.4 & 100.0 & 90.1 & 89.4 & 66.7 & 68.1 & 95.5 & 56.1 \\
\cline { 2 - 9 } & Information & 95.8 & 100.0 & 75.0 & 87.5 & 58.3 & 33.3 & 93.8 & 58.3 \\
\cline { 2 - 9 } & Retail Trade & 97.3 & 89.2 & 78.4 & 81.1 & 83.8 & 51.4 & 89.2 & 48.7 \\
\cline { 2 - 9 } & Utilities & 94.1 & 94.1 & 97.1 & 97.1 & 64.8 & 67.7 & 97.1 & 52.9 \\
\hline
\end{tabular}

Table 6: Industry trends

This is a dramatic difference that is even more extreme when manufacturing is isolated (15.2\%) and compared to the rest of the market, in which 154 of 286 companies offered Online Account Access (53.8\%). We postulate that the dramatic difference between manufacturing and the other industries in this area can be attributed to a difference in strategic emphasis. The other four largest industries (finance and insurance, information, retail trade, and utilities) are by their very nature more likely to offer services or products that require customers or users to have an account. A company such as Coca-Cola (manufacturing, www.cocacola.com) would not be as likely to offer online accounts as All-State Insurance (finance and insurance, www.allstate.com), The Gap (retail trade, www.gap.com), or PG\&E (utilities, www.pge.com) because Coca-Cola, like many other manufacturers, does not directly sell products or services online.

For the same reason, the differences between Customer Support and Online Sales offered by manufacturing and other industries are remarkable. Although trends were similar, the percentage of manufacturing companies that offered Customer Support (32.4\%) was lower than non-manufacturing companies (52.1\%). The percentage of manufacturing companies that offered Online Sales (33.3\%) was much lower than non-manufacturing companies (63.6\%). Again, this can be attributed to the fact that service-oriented sectors such as finance, information, retailers, and utilities are more likely to offer Customer Support and Online Sales because of the sales and service orientation nature of their industries.

The percentages of all eight features among the other four largest industries showed two noticeable differences. The first is the high percentage of companies within Retail Trade that offer Online Sales (see Figure 2). Manufacturing lags behind the other four industries, all of which have fairly similar levels, except for Retail $(83.8 \%)$. This is explainable by the fact the retailers have products to sell that are better suited to Online Sales than other industries. Gap (Retail Trade), as a clothing retailer, is well suited to sell its products online, whereas Gannett (Information) is unlikely to directly sell publications via its main corporate web site. Nearly $70 \%$ of utilities offered Online Sales in 2003, as paying bills online is included under the Online Sales measure. Utilities and Finance/Insurance had the highest rates of Online Account Access (see Figure 3). 


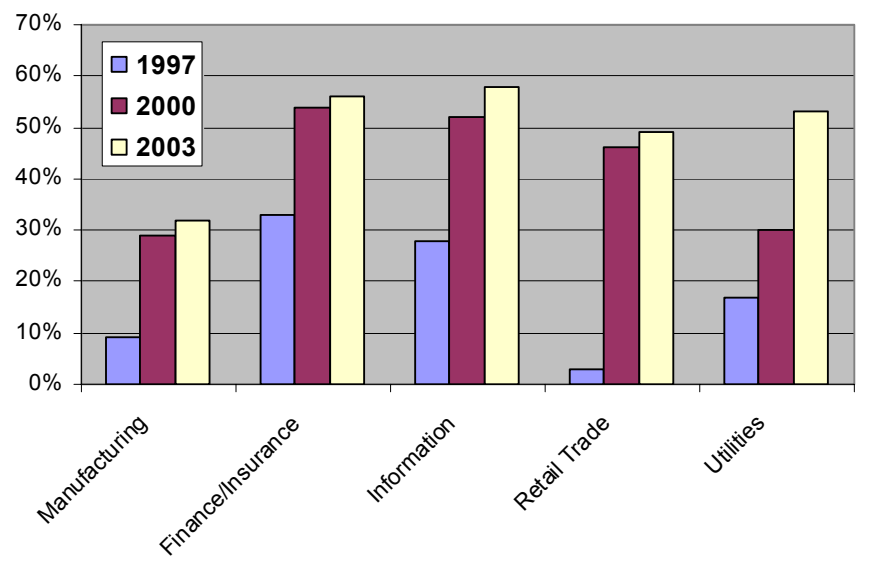

Figure 1: Customer Support levels within the five largest industries

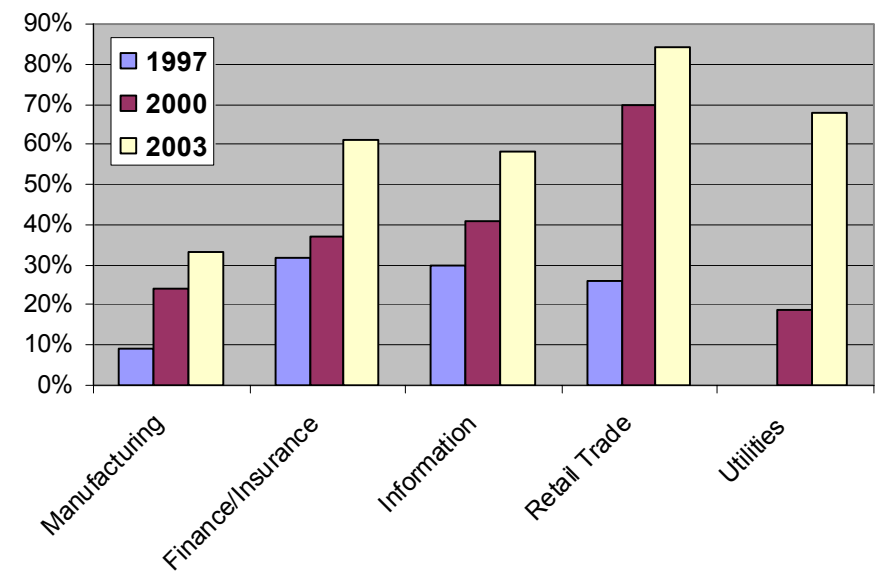

Figure 2: Online Sales levels within the five largest industries

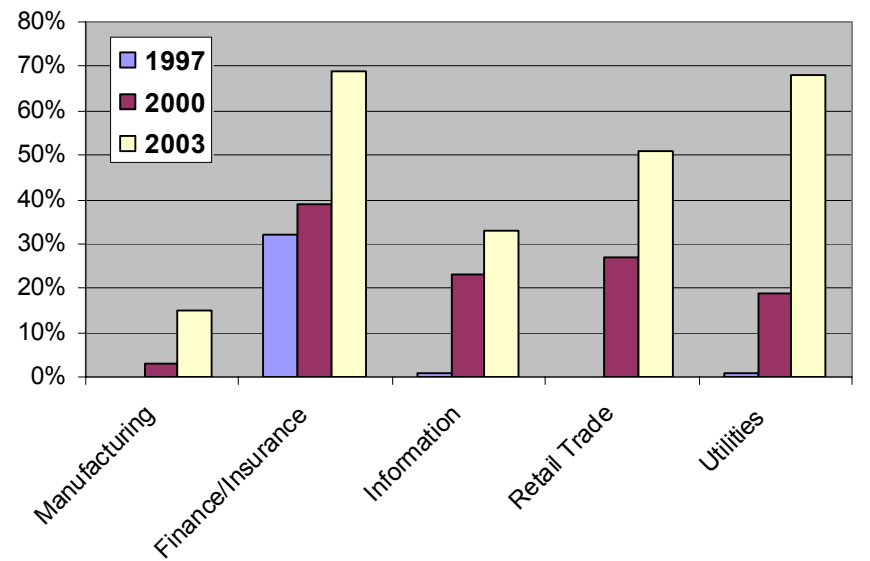

Figure 3: Online Account Access levels within the five largest industries 
Even though there are clear differences in web site features based on industry, the overall trend is a sizeable increase in the number of features offered. This can be explained be referring to one of the primary observations within this article; namely, customer perceptions of web sites are positively correlated to the number of features offered. Further, it has been indicated that customer perceptions may affect sales. As the number of features continues to rise, customers expect a certain level of information, service, and interactivity, so both the actual and expected levels of these items continue to rise. In today's ultracompetitive environment, companies must leverage every opportunity available in order to stay competitive, and creating an up to date and state-of-the-art web presence is a relatively simple way of contributing to the accomplishment of that goal. Indeed, the advancement in web design tools and software now makes it more simple and less costly than ever before to create and maintain a feature-heavy web site. It therefore should not be surprising that our survey shows an ever increasing level of web site features incorporated by large companies, and there is every reason to believe current trends will continue.

\section{CONCLUSIONS}

Our longitudinal study of the S\&P 500 web sites reveals that these web sites are incorporating more information and higher levels of interactivity than ever before. This strongly suggests that the entire population of large corporations within the United States is moving towards higher levels of information content and interactivity. Previous research has shown that customer perceptions of web sites and the associated companies are strongly influenced by information and interactivity. The positive link between perception and purchasing indicates that large companies are placing a great deal of importance on improving their web sites in hopes that financial performance will be positively affected.

The findings of this study offer practical implications to managers for creating an effective web presence that improves customer and shareholder perceptions of the company, increases customer loyalty, and therefore facilitates the execution of customer oriented e-commerce strategies. The link between features and customer perceptions and satisfaction has been welldocumented (Ghose and Dou, 1998; Teo et al., 2002; Wu 1999; Zhang and Gisela, 2000). For this reason, it is important for managers to focus on incorporating web site features that have been shown to have a positive impact on customer perceptions. Our study has shown that companies are indeed doing that on a continual basis, which is a second reason managers should monitor the moves of their peers and competitors in terms their web presence and strategies. It is essential that a company maintain pace with its industry in incorporating features and technology that consumers consider to be a given aspect of a web site. Managers should focus on implementing those features that have been shown to have the greatest effect on customer perceptions. To do this, managers must employ constant environmental scanning in order to ascertain the state of the industry. Our study should be useful for managers seeking what features have become or are becoming standard for corporate web sites.

Finally, it is important that managers incorporate web site features that help to facilitate the execution of corporate strategies. For example, an organization that emphasizes customer service should include comprehensive customer support and product information on its web site. A firm in the manufacturing industry may not choose to sell products online because that is not part of its e-commerce strategy, but a firm in the retail industry would be considered a laggard if it did not offer online sales. It is thus important that firms examine their own industry and their own business strategy to determine what web site features to implement.

The natural recommendation for further research is to more fully explore the links between customer perceptions and actual customer purchases, and between customer purchases and financial performance. This first link appears to be the more tenuous of the two because higher levels of customer purchases almost always entail better financial performance on the part of the company. It is our hope that this study can provide a solid foundation and motivation for further research on web presence, customer perceptions, and firm performance, as well as managerial insights as to what features are considered standard for corporations seeking to enhance their competitive positions.

\section{REFERENCES}

1. Amit, R. and Zott, C. (2001) Value creation in e-business, Strategic Management Journal, 22, 6/7, 493-520.

2. Agarwal, R. and Venkatesh, V. (2002) Assessing a firm's web presence: a heuristic evaluation procedure for the measurement of usability, Information Systems Research, 13, 2, 168-186.

3. Barnes, S. J. and Vidgen, R. (2003) Measuring Web site quality improvements: a case study of the forum on strategic management knowledge exchange, Industrial Management \& Data Systems, 103, 5, 297-309.

4. Chen, P.Y. and Hitt, L.M. (2002) Measuring switching costs and the determinants of customer retention in Internetenabled businesses: A study of the Online brokerage industry, Information Systems Research, 13, 3, 255-274.

5. Devaraj, S., Fan, M. and Kohli, R. (2002) Antecedents of B2C channel satisfaction and presence: validating ecommerce metrics, Information Systems Research, 13, 3, 316-333. 
6. Ghose, S. and Dou, W.Y. (1998) Interactive functions and their impacts on the appeal of internet presence sites, Journal of Advertising Research, 38, 2, 29-43.

7. Han, K.S. and Noh, M.H. (winter 1999-2000) Critical failure factors that discourage the growth of electronic commerce, International Journal of Electronic Commerce, 4, 2, 25-43.

8. Huizingh, E.K.R.E. (2000) The content and design of web sites: an empirical study, Information \& Management, 37, 3 , $123-134$.

9. Janda, S., Trocchia, P.J. and Gwinner, K.P. (2002) Consumer perceptions of Internet retail service quality, International Journal of Service Industry Management, 13, 5, 412-431.

10. Jarvenpaa, S.L. and Todd, P.A. (winter 1996-1997) Consumer reactions to electronic shopping on the World Wide Web, International Journal of Electronic Commerce, 1, 2, 59-88.

11. Keeney, R.L. (1999) The value of internet commerce to the customer, Management Science, 45, 4, 533-542.

12. Khalifa, M. and Liu, V. (2002) Satisfaction with Internet-based services: The role of expectations and desires, International Journal of Electronic Commerce, 7, 2, 31-49.

13. Kim, J., Lee, J., Han, K., and Lee, M. (2002) Business as buildings: metrics for the architectural quality of internet businesses, Information Systems Research, 13, 3, 239-254.

14. Koufaris, M., Kambil, A. and LaBarbera, P.A. (winter 2001-2002) Consumer behavior in web-based commerce: an empirical study, International Journal of Electronic Commerce, 6, 2, 115-138.

15. Lee, M. and Turban, E. (2001) A trust model for consumer Internet shopping, International Journal of Electronic Commerce, 6, 1, 75-91.

16. Liu, C. and Arnett, K.P. (2000) Exploring the factors associated with web site success in the context of electronic commerce, Information \& Management 38, 23-33.

17. Madeja, N. and Schoder, D. (2002) Designed for success - empirical evidence on features of corporate web pages, Proceedings of the 36th Hawaii International Conference on System Sciences, (HICSS'03), IEEE.

18. McKinney, V., Yoon and K. Zahedi, F. (2002) The measurement of web-customer satisfaction: an expectation and disconfirmation approach, Information Systems Research, 13, 3, 296-315.

19. McKnight, D.H., Choudhury, V. and Kacmar, C. (2002) Developing a validating trust measures for e-commerce: an integrative typology, Information Systems Research, 13, 3, 334-359.

20. Morris, M.G. and Turner, J. (2001) Assessing users' subjective quality of experience with the world wide web and exploratory examination of temporal changes in technology acceptance, International Journal of Human-Computer Studies, 54, 6, 877-901.

21. Palmer, J.W. (2002) Web site usability, design, and performance metrics, Information Systems Research, 13, 2, 151-167.

22. Reibstein, D.J. (2002) What attracts customers to online stores, and what keeps them coming back? Academy of Marketing Science Journal, 30, 4, 465-473.

23. Reichheld, F.F. and Schefter, P. (2000) E-loyalty - your secret weapon on the web, Harvard Business Review, 78, 4, 105 .

24. Rust, R.T. and Lemon, K.N. (2001) E-Service and the consumer, International Journal of Electronic Commerce, 5, 3, 85-101.

25. Straub, D.W., Hoffman, D.L., Weber, B.W. and Steinfield, C. (2002) Measuring e-commerce in net-enabled organizations: an introduction to the special issue, Information Systems Research, 13, 2, 115-124.

26. Teo, H., Oha, L., Liu, C. and Weib, K. (2003) An empirical study of the effects of interactivity on web user attitude, International Journal of Human-Computer Studies, 58, 3, 281-305.

27. Torkzadeh G. and Dhillon, G. (2002) Measuring factors that influence the success of Internet commerce, Information Systems Research, 13, 2, 187.

28. United States Department of Commerce. (2003) Retail e-commerce sales in third quarter 2003 were $\$ 13.3$ billion, up 27.0 percent from third quarter 2002, Census Bureau Reports, 2003. http:/www.census.gov/mrts/www/current.html.

29. Wan, H.A. (2000) Opportunities to enhance a commercial web site, Information \& Management, 38, 1, $15-21$.

30. Wu, G. (1999) Perceived interactivity and attitude toward web site, Proceedings of 1999 Annual Conference of American Academy of Advertising, NM.

31. Zhang, P. and Dran, G.M. (2000) Satisfiers and dissatisfiers: a two-factor model for web site design and evaluation, Journal of the American Society for Information Science, 51, 14, 1253-1268.

32. Zhang, P. and Dran, G.M. (winter 2001-02) User expectations and rankings of quality factors in different web site domains, International Journal of Electronic Commerce, 6, 2, 9-33.

33. Zhu, K. and Kraemer, K.L. (2002) E-commerce metrics for net-enhanced organizations: assessing the value of ecommerce to firm performance in the manufacturing sector, Information Systems Research, 13, 3, $275-295$. 